\title{
Meta-analysis of community's adaptation pattern with tidal flood in Pekalongan City, Central Java, Indonesia
}

\author{
Fara Dwi Sakti Kartika ${ }^{1, *}$, Muhammad Helmi $^{2}$, Amirudin $^{3}$ \\ ${ }^{1}$ Magister of Environmental Science, School of Postgraduate Studies, Diponegoro University, Semarang - Indonesia \\ ${ }^{2}$ Department of Oceanography, Faculty Of Fisheries And Marine Sciences Diponegoro University, Semarang - Indonesia \\ ${ }^{3}$ Department of Anthropology, Faculty of Humanity, Diponegoro University, Semarang - Indonesia
}

\begin{abstract}
In the last two decades, northern coast Java Island occasionally experienced a tidal flood. One of area that affected by tidal flood is Pekalongan City, a small city in Central Java. Many studies have been conducted to investigate this issue. The area of investigation includes physical damage and people's adaptation with tidal flood. This paper tries to explore people's adaptation pattern in Pekalongan City with tidal flood. The meta-analysis approach was adopted as there are many papers that had investigated this phenomenon. This paper shows that community's adaptation patterns in Pekalongan city tidal flood are divided into two response patterns, cognitive map and artifact patterns. These patterns have produced a new way of life or culture in the community. By understanding how people adaptation with tidal flood, hopefully, scientist and policymaker can bring more appropriate solution or policy to help people's adaptation with tidal flood or how they minimize tidal flood effect in more sustainable way.
\end{abstract}

Keywords: Tidal Flood; adaptation pattern; environment anthropologie.

\section{Introduction}

The northern coast of Java island has experienced tidal flood and abrasion in recent decades. Land Subsidence that occurs on several beaches in Java Island is increasingly expanding tidal flooding in several cities on the north coast of central Java such as Semarang, Demak, Jakarta, and Pekalongan [20]. Research shows that flood along the northern coast of the island of Java due to tidal flood is much faster and exceeds the geological time scale. Analysis using spatiotemporal high-resolution satellite imagery shows that tidal inundation area continues to grow and protrudes into settlement area. Fishponds and agriculture are two activities that affected badly by tidal flood [1].

This research focused on Pekalongan City, one of the Cities in Central Java Province which experienced tidal flood. Pekalongan City is a lowland on the north coast of Java Island, with a height of $\pm 1 \mathrm{~m}$ above sea level and a geographical position between 6050'42 '- 6o55'44' 'South Latitude (LS) and 109037'55' '- 109042' 19 " East Longitude (BT). The tidal floods that have occurred in Pekalongan City have not been handled well compared to Semarang City, the capital of Central Java that also located in north coast of Java Island. Semarang City has used retention ponds, polders and reclamation and plans for the sea dike toll road to manage tidal flood.

Tidal floods that submerged eight villages in Pekalongan City resulted in port paralysis, settlement damage and damage to residential areas [9]. Based on this research, the average flood rate is around $10-50 \mathrm{~cm}$ and the maximum height is $70 \mathrm{~cm}$. Tidal floods in Pekalongan almost occurred every day for the last 10 years. It mainly hit Kelurahan, bahasa for urban village, which borders with the sea.

In Pekalongan City there are varied land changes (increasing or decreasing). From 1999 - 2012 the use of inundation land was the widest which experienced extensive additions, from \pm 13.45 ha to \pm 348.37 ha, whereas Empty land use is the widest experiencing a reduction, namely from \pm 799.77 ha to \pm 6.91 ha [19].

Syams Nashrrullah (2013) using MIKE-21 modeling predicted and simulated inundation area in Pekalongan City. The result shows that the inundation area was linear with the rate of land subsidence. Applying three different scenarios: at this time, then 50 years with no sea-level rise and next 50 years with $50 \mathrm{~cm}$ of sea-level rise, sea-level rise range in Pekalongan for each scenario would be $0.23-1.27 \mathrm{~m}, 0.36-1.38 \mathrm{~m}$, and $0.65-1.53 \mathrm{~m}$, respectively. On the other hand, remote sensing analysis using ALOS/ PALSAR image and Differential Interferometric Synthetic Aperture Radar (D-InSAR) data between 2008 and 2009 shows that the average Land Subsidence rate in Pekalongan City is $3 \mathrm{~cm} /$ year, and it mainly occurs in west of the city. The other Research of Land subsidence in Pekalongan city shows that land subsidence occurs in Pekalongan city, from the results of

\footnotetext{
* Corresponding author: faradwisaktikartika@gmail.com
} 
the analysis of the InSAR images in Pekalongan at the rate of $4.8-10.8 \mathrm{~cm} /$ year .

The tidal flood that occurred in Pekalongan city was initially only a few centimeters inundation and only came at high tide, but now it can be more than half a meter and comes in ordinary tide, and has even come permanently in certain places. Pekalongan City approximately 13.8 hectares experiencing tidal floods [1].

Identification of events and impacts of tidal flooding and disaster mitigation as part of disaster risk management to reduce losses due to inundation of tidal floods in Pekalongan Kota shows that tidal floods have inundated 9 Kelurahan in Pekalongan Utara sub-district [2]. Tidal inundation occurs almost every day with inundation depths ranging from 30 to $50 \mathrm{~cm}$ in the surrounding environment. The inundation enters houses with 15 to $40 \mathrm{~cm}$ of height. The tidal flood caused a decline in agricultural productivity and damage to buildings. Mitigation measures, as one of the disaster management efforts carried out by the government and the local community, still focus mainly on structural measures. [2]

Coastal communities depend on the condition of coastal land to survive and work. Tidal floods greatly affect coastal communities economically because they inundate these valuable areas as ponds, agricultural land, and settlements, and are expected to develop due to the influence of sea-level rise [6]. Damaging regional assets reduces the chances of coastal communities, especially the poor, to improve their welfare [2]. Research on the risk of tidal flood inundation and identify mitigation efforts carried out by both the government and coastal communities in Pekalongan City.

According to Twigg [5], disasters will occur when people get danger and provide extraordinary conditions such as death, injury, loss of property, and economic losses.

There are various land uses and economic activities taking place in the coastal areas of Pekalongan City. Different land uses are affected by inundation floods. In the east and west of coastal areas, such as Degayu, Krapyak Lor, Bandengan, and Kandang Panjang, land use is dominated by ponds, agriculture, and residential areas. While in the central part of coastal areas, such as in Panjang Baru and Panjang Wetan, land use is characterized by residential areas and ponds, [2].

Flood vulnerability is explained by exposure, sensitivity and adaptive capacity. However, the aspect of exposure is the biggest variable in describing the flood vulnerability of the north coast of Central Java province. The exposure itself consists of frequency of floods, duration of floods, number of elderly and infants, and distance of settlements from flooded areas. At the same time, the biggest variable that determines community resilience is damage, followed by personal losses and casualties. Among the aspects of flood vulnerability, exposure and adaptive capacity determine the resilience of communities on the northern coast of Central Java. [7]

Research on community resilience to flooding in the coastal zone for disaster risk reduction, Pekalongan is the most vulnerable zone, the area is vulnerable compared to other regions, namely Semarang and Pati and it is classified as a place with high vulnerability. The result is similar to the Flood Risk Index released in 2014 by BNPB. The high level of vulnerability in Pekalongan was triggered by high frequency of flooding, high tidal floodwater, duration of floods and ineffective management of local government. It is also influenced by human factors, as indicated by the fact that $79.4 \%$ of the local population works as farmers or fishermen. In addition, $81.5 \%$ of respondents only had basic education (elementary and junior high school) and $76.3 \%$ of them produced $\leq 1$ million Rupiah a month [7].

The response of flooding from the people living is to adapt or pattern response. Patterns of response to actions or community adaptations based on reasoned actions that require sustainability and adjust to their environment [14].

\section{Materials and Method}

This research is literature study and field observations regarding tidal flooding that occur in Pekalongan City are viewed from the perspective of environmental anthropology, namely how the pattern of response strategies survives the effects of tidal flooding. Literature study method or review of some literature (literature review) by collecting data and information on various journals and bulletins relating to the location of the study. Field observations were carried out by conducting indepth interviews with several key people who lived in the study area and were considered to understand the effects of tidal flooding because they had experienced tidal flooding for a long time.

The results of this study use descriptive exploratory and environmentalism approaches to describe further information using more adaptive and flexible methods. The results will be discussed through the description and explanation according to the method that is suitable for the purpose.

\section{Result and Discussion}

The pattern of activities of the people of northern Pekalongan who experience tidal floods is broadly divided into 2 (two) response patterns, namely those called nonmaterial (cognitive map) and material (artifact patterns [14].

Characteristics of social and cultural phenomena are identified by comparing them, and the factors that produce and influence them are isolated by comparing the context in which they occur [16]. 


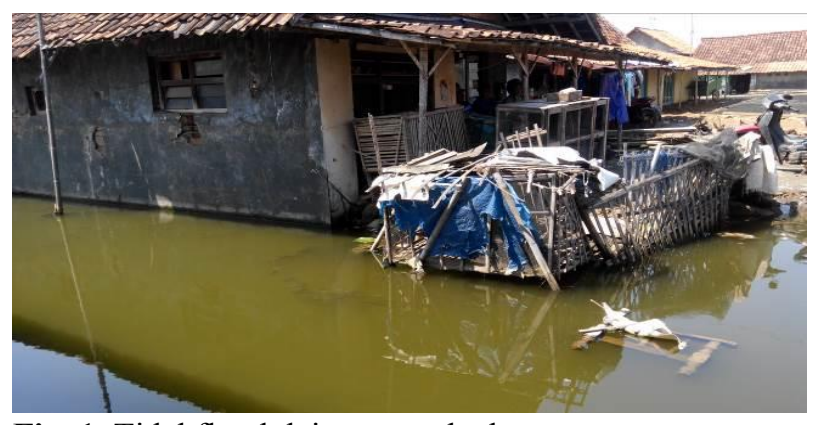

Fig. 1. Tidal floodplains enter the house

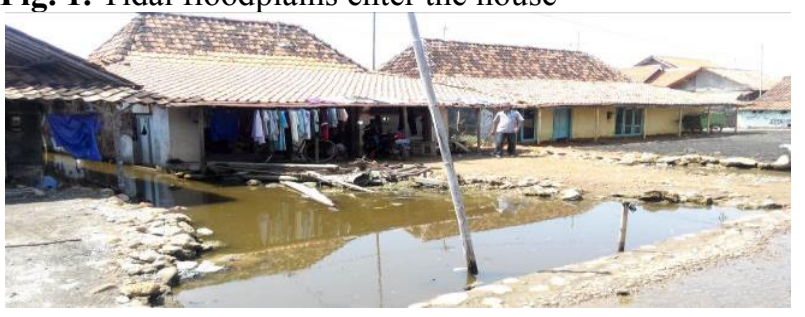

Fig. 2. Material response pattern (artifacts) Society elevates the house.

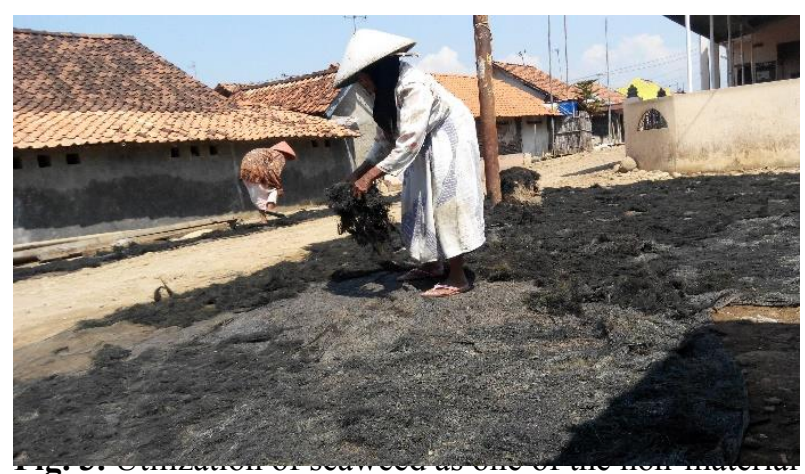

(cognitive map) response patterns in the face of tidal flooding.

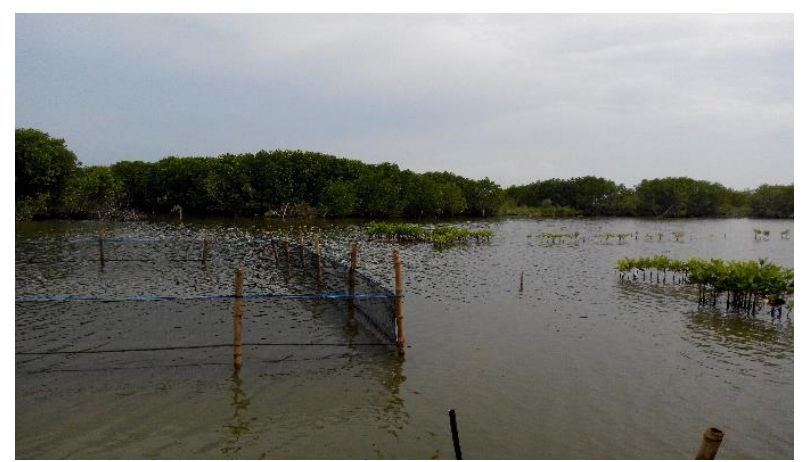

Fig. 4. Ponds of the people of Pekalongan Utara that used to be agricultural land

In the discussion of this response pattern, there are 2 things, namely environmental determinism and cultural determinism. environmental determinism is an environment forming a culture because it is a culture that adapt to the environment. Whereas cultural determinism is that humans adjust their environment according to their own needs so they determine or shape their environment to be in accordance with their needs [14].

The tidal flood phenomena in Pekalongan City, especially Pekalongan Utara Subdistrict brings a pattern of response from the community to adapt. Adaptation has been made to tidal floods which are generally part of this 'initial climate change disaster' such as building embankments, elevating land, houses, infrastructure, etc.

People in North Pekalongan experienced tidal floods that were not permanent, starting in 2000, but starting in 2008 the water did not recede until it reached the settlements, creating a new pattern of artifacts, namely by raising the floor of the house. This is so that inundation water does not reach inside the house. This phenomenon makes the height of houses and even long-term house artifacts with very short doors and when they enter the house they must bow first.

Another material response pattern is building sea dikes. This sea wall is a mitigation effort carried out by the government and the community in tackling tidal flooding. The installation of a 3 meter high embankment with a length of $7.2 \mathrm{~km}$ is expected to be effective enough to overcome tidal flooding. The other material response pattern is the installation of pumps that will be placed in long storage to remove stagnant water from tidal flooding.

The phenomenon of tidal flooding in Pekalongan has made environmental conditions worse, Saline water is the most common problem of water quality in the coastal city, especially in developing countries such as Indonesia. [17]. In fulfilling water needs the community uses underground water sources known as Pamsimas and PDAM. Water conditions in PDAM that are not smooth cause seawater to enter the pipes, causing the water to be unsuitable for consumption and the people of North Pekalongan prefer to use underground water sources again. The use of underground water sources is actually not good for the environment itself, Based on laboratory tests show that Pekalongan city intrusion on high category [17]. The region within distance $500-600 \mathrm{~m}$ from the coastline has salinity level of 6,7 to $15.5 \%, 800-900 \mathrm{~m}$ has a salinity level of 2,9 to $6.6 \%, 1-1.5 \mathrm{~km}$ has a salinity level of 1,4 to 2,8 .

The pattern of adaptation of the people of North Pekalongan does not have many choices so that the 2 alternatives can meet domestic water needs. However, to fulfill their drinking water needs, they consume water in the packaging brought in from the surrounding area. So that in this case cultural determinism also appears to be applied by the people of northern Pekalongan in the pattern of material response [14].

The pattern of non-material (cognitive map) responses in the Pekalongan Utara community appears from changes in people's livelihoods, which they used to farm and their land is always flooded, so it changes, but there are some pond areas that cannot be cultivated so that people change to fishing seaweed. Namely looking for seaweed to be used and sold for living needs.

\section{Conclusion}

The tidal flood that hit the northern city of Peklongan brought a pattern of adaptation response to the people who were flooded with settlements and their livelihoods. The pattern of response establishes to a new culture of both non-material (cognitive map) such as changes in 
livelihoods and material (artifact patterns) such as elevating the building of a house with a drop of land. Tidal flood has an effect on establish a pattern of community response specifically in the community of Pekalongan City. The POla response is manifested in immaterial and material actions.

\section{References}

1. H.Andreas, H.Z.Abidin,D.A.Sarsito., D. Pradipta. Adaptation of 'Early Climate Change Disaster' to the Northern Coast of Java Island Indonesia. Engineering Journal, 22 Issue 3: 208-219 (2018)

2. N.M. Ni'mah,S.Fathurrohmah, R.Septriayadi. Paper Presented in Track A Climate Change and Natural Disaster at the 2nd ICRD, 20-21 (2013)

3. A.M. Lubis, T. Sato, N. Tomiyama, N. Isezaki, and T. Yamanokuchi, Ground subsidence in SemarangIndonesia investigated by ALOS-PALSAR satellite $S A R$ interferometry, Journal of Asian Earth Sciences, 40: 1,079-1,088 (2011)

4. S.Nashrrullah, Aprijanto, J.M.Pasaribu, M.K. Hazarika, L.Samarakoon. Study Flood Inundation in Pekalongan Cntrl Java. International Journal of Remote Sensing and Earth Sciences, 10, 2: 76-83 (2013)

5. J. Twigg. Disaster risk reduction: mitigation and preparedness in development and emergency programming. Humanitarian Practice Network Good Practice Review No. 9 (2004)

6. H. Prihatno. Identification and mapping of coastal flood impacts: a case study of the coastal area of Pekalongan, Central Java. Thesis, UGM (2011)

7. M.Isa, FX. Sugiyanto,, I. Susilowati. Community resilience to floods in the coastal zone for disaster risk reduction. Journal of Disaster Risk Studies. 1-7 (2018)

8. Marfai, M.A. and L. King, Monitoring land subsidence in Semarang, Indonesia. Environ. Geol, 53: 651-659 (2007)

9. National Disaster Management Agency (BNPB), 2010, National Disaster Management Plan 20102014, BNPB, Jakarta.

10. National Disaster Management Agency (BNPB), 2016, Data Disaster Information Indonesia, BNPB, Jakarta.

11. E.Chaussard, F.Amelung, H.Abidin, and S.H. Hong, Sinking cities in Indonesia: ALOS PALSAR detects rapid subsidence due to groundwater and gas extraction. Remote Sensing of Environment, 128: 150-161 (2013)

12. Ng, A.H.M., L. Ge, X. Li, H.Z. Abidin, H. Andreas, and K. Zhang, Mapping land subsidence in Jakarta, Indonesia using persistent scatterer interferometry (PSI) technique with ALOS PALSAR. International Journal of Applied Earth Observation and Geoinformation, 18:232-242. (2012)
13. A.T Priyanto, The impact of human activities on coastal zones and strategies towards sustainable development: A Case Study in Pekalongan, Indonesia. Thesis. ITC, University of Twente (2010)

14. M. Key. Environmentalism and cultural Theory, Explorig the role of anthropology in enviromemntal discourse. Routledge Canada. (1996)

15. Amirudin. Multiculturalism Practices Associated with the Production of Batik in Lasem - Indonesia. International Journal of Global Community, I (2018)

16. James P. Spradley. Metode Etnografi (terjemahan). Yogyakarta: Tiara Wacana (2007)

17. Suharini, E. Study of Population Growth and Land Use Change Impact of Intrusion at Pekalongan City. Advances in Social Science, Education and Humanities Research, 79 (2016)

18. Chaussard E., Amelung F., Abidin H. and Hong SH., Sinking cities in Indonesia: ALOS PALSAR detects rapid subsidence due to groundwater and gas extraction, Remote Sens. Environ. 128 150-61 (2013)

19. Rina, S., Subarji, P., Oraktikno,I. Analisis perubahan penggunaan lahan di wilayah pesisir Kota pekalongan menggunakan data landsat $7 \mathrm{etm}+$. Journal Of Marine Research (2013)

20. Sarah D, Soebowo E., Land subsidence threats and its management in the North Coast of Java. IOP Conf. Series: Earth and Environmental Science, 118 (2018) 